\title{
Tools to Improve the Efficiency of Import Substitution in the Agro-industrial Complex Under Economic Sanctions
}

\author{
Submitted 08/02/19, 1st revision 16/03/19, 2nd revision 17/05/19, accepted 07/06/19
}

\author{
Terenina I.V. ${ }^{1}$, Kostoglodov D.D. ${ }^{2}$, Kiyanova L.D. ${ }^{3}$, Usatkina O.I. ${ }^{4}$
}

\begin{abstract}
:
Purpose: This article is concentrated on the creation of a uniform risk management system in agro-industrial complex which can increase efficiency of control over compliance with non-tariff restrictions and will strengthen protection of agricultural producers against importing sanctions.

Structure/Methodology/Approach: If it is necessary to evaluate the prospects of increasing efficiency of import substitution in agro-industrial complex in the conditions of sanctions first, you need to allocate types of import dependence of various branches. Second, you need to analyze the main instruments of implementation of import substitution policy. Third, you need to create a uniform risk management system in the Eurasian customs' territory for increasing efficiency of import substitution.

Findings: The authors offer creation of a uniform risk management system which application will increase efficiency of control over compliance with non-tariff restrictions.

Practical Implamentation: Results can be implemented in administrative practice for the purpose of increasing efficiency of import substitution in the agro-industrial complex.

Originality/value: The main contribution of this research consists in development of the system of increasing effective risk management in member states of EEU.
\end{abstract}

Keywords: Import substitution, sanctions, risk management system, foreign trade.

JEL Codes: F02, F14,F15.

Paper Type: Research article in Special Issue dedicated to Russian Economy.

Section 7: Economic Development.

\footnotetext{
${ }^{I}$ Doctor of Science (Economics), Professor of marketing and engineering Economics Department, Don State Technical University, Rostov-on-Don, teririn@yandex.ru

${ }^{2}$ Doctor of Science (Economics), Professor of Marketing and advertising Department, Rostov State

University of Economics, Rostov-on-Don, d.d.kostoglodov@yandex.ru

${ }^{3}$ Candidate of Economic Sciences, Associate Professor, the Department of Management and Economics of Customs Affairs, Rostov Branch of Russian Customs Academy,Rostov-on-Don, liliackgti@mail.ru

${ }^{4}$ Candidate of Science (Economics), Associate Professor of marketing and engineering Economics

Department, Don State Technical University, Rostov-on-Don, olga_usatkina@mail.ru
} 


\section{Introduction}

The financial and economic crises of the last decades have exposed new external challenges containing serious risks and threats to Russia's national security. In the economic security Strategy of the Russian Federation for the period up to 2030, economic security refers to the state of protection of the national economy from external and internal threats, which ensures the economic sovereignty of the country, the unity of its economic space, the conditions for the implementation of the strategic national priorities of the Russian Federation (Government of the Russian Federation. 2017). Among the main challenges and threats to economic security listed in the Strategy are, among others, changes in the structure of global energy demand and consumption patterns, the development of energy-saving technologies and reduction of material intensity, the development of "green technologies"; exhaustion of the export-raw material model of economic development, a sharp decline in the role of traditional factors of economic growth associated with scientific and technological changes; the absence of Russian non-resource companies among the global leaders of the world economy; limited scope of Russian non-commodity exports due to its low competitiveness, underdeveloped market infrastructure and weak involvement in global value "chains" (Government of the Russian Federation. 2017) . Thus, we agree that the fundamental strategic risks and threats to Russia's economic security in the long term are the preservation of the export-raw material model of the national economy, the decline in competitiveness and the high dependence of its most important areas on the external economic situation (Jabiev, 2015; Gumidullaeva, 2018).

Executive authorities in the context of global challenges and threats to the changing world should protect domestic producers, preserve intellectual property and promote foreign trade activities. The foreign trade policy of any state can be implemented in two ways: through the policy of import substitution, which provides for protectionist measures, and through free trade or free trade. Since early 2000 of our country deliberately came to the need of import substitution. Many elements of this policy were formed in 1990, however, an integrated system at that time has not yet developed. The impetus for the implementation of the policy of import substitution in full gave the introduction of sanctions against Russian companies by Western countries and the response of sanctions in some sectors of the economy. In March 17, 2014 in connection with the Ukrainian crisis began the first wave of sanctions by the US and the EU. Sanctions against Russia acted in three directions:

- sanctions restricting access to capital markets;

- sanctions against some state politician leaders;

- sanctions that restricted the import of technological equipment for the oil and gas industry.

By September 2014, the sanctions regime of the USA and the EU included all the major banks of the Russian Federation, oil and gas companies, enterprises of the 
military-industrial complex. Russia in response to Western sanctions imposed restrictive measures. The main restriction of imports in the Russian Federation is the decree of the President of Russia dated 06.08.2014 "on the application of certain special economic measures to ensure the security of the Russian Federation", which approved the list of agricultural products, raw materials and food, the import of which from the countries applying sanctions against Russia, is prohibited. Currently, the list of sanctioned goods and restrictive measures on both sides continues to be prolonged and extended, the validity of this ban is extended until December 31, 2019 (Government of the Russian Federation, 2014).

In addition to the sanctions imposed by Western countries, the devaluation of the ruble in 2014 also influenced the choice of import substitution strategy in the Russian Federation. Thus, for the period from January 2014 to December 2014, the ruble against the dollar and the Euro decreased by $72.3 \%$ and $51.7 \%$, respectively (Central Bank of the Russian Federation 2019). Subsequently, the Central Bank of Russia adjusted the key rate and raised it from $9.5 \%$ to $17 \%$. Thus, due to a sharp jump in the dollar and the Euro against the ruble, the Russian economy faced a currency deficit and a rise in the price of foreign goods, which led to the need to replace imported goods with national ones.

It should be noted that even before the introduction of anti-Russian sanctions, Western countries actively used the right not to sell dual-use goods and technologies to Russia, based on the provisions of the Wassenaar arrangement. That is, sanctions have only made this practice imperative. However, to a greater extent, Russia has felt the consequences of the sanctions imposed by Western countries due to the sharp fall of the ruble, oil prices. After the introduction of sanctions in the oil and gas industry, the cost of oil as of December 2015 per barrel fell to a critical level in the previous five years, which predetermined for Russia the need for an urgent response to this fact (Yandex: economic news, 2018).

Sanctions and food embargoes have created a noisy propaganda campaign, the decisions taken initially were not always properly worked out and justified in economic and social terms. Currently, import substitution in both legal and practical terms has become systemic and widespread. According to the Concept of long-term socio - economic development of the Russian Federation for the period up to 2020, it is planned to change the structure of sources of coverage of domestic demand growth towards a significant increase in the share of domestic production: in 2007 it accounted for 51.3 sources of domestic demand (imports - 48.7), according to the Concept it is planned to increase the share of domestic production to 76.4 percent by 2020 (imports-23.6 \%) (Government of the Russian Federation, 2008).

However, it should be remembered that the development of the Concept was carried out in a period favorable for the development of the Russian economy, characterized primarily by high energy prices and, accordingly, high growth rates of the gross domestic product of the Russian Federation. The change in the situation on the 
commodity market has made serious adjustments to the forecasts of the national economy of Russia, but at the same time further actualized the need to replace imports and move away from the raw material model of economic development. The current state of the fuel and energy complex, and, as a result, a sharp fall in the ruble exchange rate, anti-Russian sanctions, a tense geopolitical crisis, will keep import substitution on the economic and political agenda for a long time.

Total import substitution in our country today is inefficient and impossible, although in most sectors and sectors of the Russian economy it is an objective necessity (Erokhina E., 2017). Import substitution in any industry will be possible in the event of the release and creation of new production facilities and technological enterprises capable of competing with foreign players on market conditions. In addition, the positive dynamics and effect of import substitution can become noticeable only in the medium or long term. Various types of import dependence are typical for different sectors of the Russian economy. Three types of import dependence can be distinguished (Figure 1) and, accordingly, different variants of import substitution policy implementation.

Figure 1. Types of import dependence

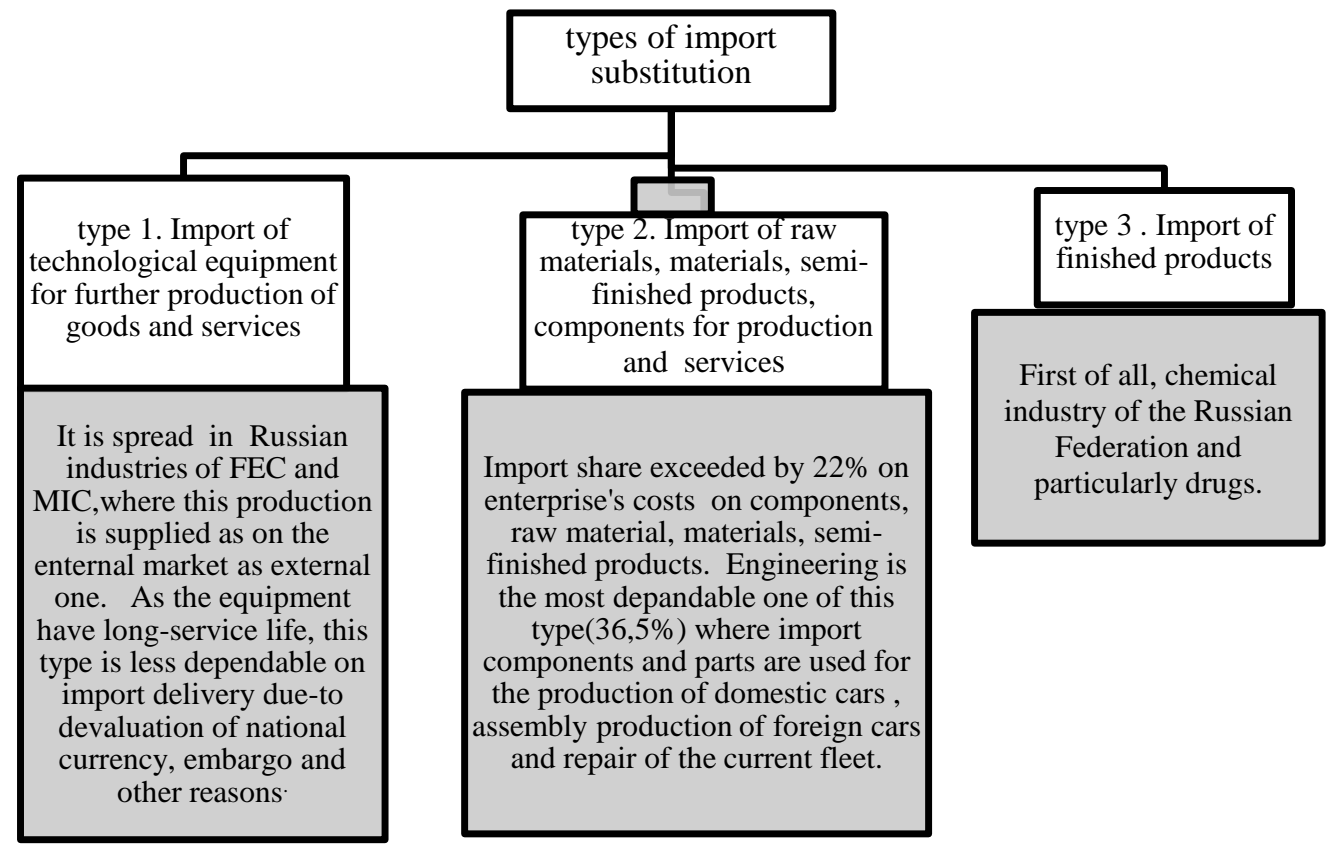

Food security is an important area of ensuring the country's national security in the medium term, a factor in preserving its statehood and sovereignty, an important component of demographic policy, a necessary condition for the implementation of the strategic national priority to improve the quality of life of Russian citizens by guaranteeing high standards of life support (Government of the Russian Federation. 
2010). Food security of the Russian Federation is the state of the country's economy, which ensures the food independence of the Russian Federation, guaranteed physical and economic accessibility for every citizen of the country of food products that meet the requirements of the legislation of the Russian Federation on technical regulation, in the amount of not less than the rational norms of food consumption necessary for an active and healthy lifestyle (Government of the Russian Federation, 2010). Implementation of the policy of import substitution in the sphere of food production is a priority task of the state policy of the Russian Federation.

It is necessary not only to reduce the share of imported food in the Russian market (some progress has been made in this direction), but also to reduce the dependence of the agricultural sector on imported resources, machinery and equipment. In the field of foreign economic policy, it is important to promptly apply customs and tariff regulation measures to rationalize the ratio of exports and imports of agricultural and fish products, raw materials and food. At the Disposal of the Government of the Russian Federation of December 28, 2012 No. 2575-p "on the development Strategy of the Customs service of the Russian Federation until 2020" states that the Customs service of the Russian Federation is an integral part of the system of state management of foreign trade activities. It acts as one of the main instruments of its regulation, combining the functions of fiscal, law enforcement and Supervisory authority, at the same time contributes to the development of foreign economic activity. The effectiveness of the customs authorities depends on the observance of the food embargo, and, accordingly, the effectiveness of protectionist measures in the field of agro- industrial sector. In the context of the common customs territory of the EAEU, the task of combating the import of sanctioned goods is complicated, therefore, it is necessary to identify ways to improve the mechanism of customs regulation in order to improve the efficiency of the policy of import substitution in the agro- industrial sector.

\section{Materials and Methods of Research}

In the framework of the formulated problems in the course of the study, the authors used the following research methods: analysis, synthesis, method of deduction, method of system analysis, as well as graphical method. The authors studied the legal and strategic documents regulating the implementation of the policy of import substitution in the Russian Federation, analyzed a large array of statistical data characterizing the development of foreign trade in food products.

Analysis of the intermediate results of the implementation of the policy of import substitution in the agro-industrial sector:

Among the experts there are different opinions on the factors and methods necessary to improve productivity, production volumes in the agro-industrial complex. We adhere to the point of view that the production of import-substituting products in the agricultural sector is based on six main factors: the cost of used machinery and 
equipment, energy, raw materials, labor, availability of financial resources, as well as the level of development of management and staff skills. Only with a competent and balanced combination of these factors is it possible to create effective and competitive agro-industrial production. As the main tools for the implementation of import substitution policy in the agro-industrial sector, used in Russia, we can distinguish the following:

1. Financial support of technical modernization of the agro-industrial complex, which involves primarily increasing the availability of investment resources (subsidizing the interest rate on investment loans).

2. Implementation of programs and projects with the participation of state bodies in those sectors of the agro-industrial complex, which provide accelerated import substitution of the main types of agricultural products, raw materials and food.

3. Providing subsidies from the Federal and regional budgets of the Russian Federation.

4. Assistance in the organization of fairs, exhibitions for entrepreneurs interested in import substitution, and the population.

The most important documents defining the main directions of import substitution in the agro-industrial complex are the decree of the government of the Russian Federation of 14.07.2012 № 717 "on the state program of development of agriculture and regulation of markets of agricultural products, raw materials and food for 2013 2020", the Decree of the President of the Russian Federation of August 6, 2014 № 560 "on the application of certain special economic measures to ensure the security of the Russian Federation", the Order of the Government of the Russian Federation of October 02, 2014. № 1948 "on approval of the action plan to promote import substitution in agriculture".

The objectives of the State program for the development of agriculture and regulation of markets for agricultural products, raw materials and food for 2013-2020 is to ensure food independence in the parameters set by the Doctrine of food security; accelerated import substitution in respect of meat (pork, poultry, cattle), milk, vegetables, open and closed ground, seed potatoes and fruit and berry products; improving the competitiveness of Russian agricultural products in the domestic and foreign markets (Ministry of Agriculture, 2017). As you can see, the main vector of the program is the replacement of imported food products of high quality domestic.

The food embargo has given some impetus to agricultural production. Thus, the production of cattle meat (beef and veal) steamed, cooled or chilled, including for baby food increased by $6.2 \%$; the production of meat of cattle (beef and veal) frozen, including for baby food by $16.5 \%$; the production of marine live fish, which is not a product of fish farming by $81.9 \%$; the production of vegetables (except potatoes) and frozen mushrooms by $9.5 \%$; production of liquid processed milk, including milk for baby food-by $2.1 \%$; production of cream by $2.5 \%$. 
At the moment, the indicators of food independence specified in the Doctrine of food security have been achieved for basic food products (Table 1):

Table 1. Share of Russian food products in the total volume of domestic market resources, as a percentage (Ministry of Agriculture, 2018)

\begin{tabular}{|l|c|c|}
\hline \multicolumn{1}{|c|}{ The name of the product } & Defined in the Doctrine & in fact in 2017 \\
\hline Bread and bread products & 95 & 99 \\
\hline Vegetable oil & 80 & 85 \\
\hline Sugar & 80 & 95 \\
\hline Potatoes & 95 & 97 \\
\hline Milk and dairy products & 90 & 82 \\
\hline Meat and meat products & 85 & 90 \\
\hline
\end{tabular}

At the same time, protectionist measures can bring benefits to producers and loss to buyers. So, only from August 2014 to the end of 2015, prices for fresh cucumbers increased more than three times, tomatoes -2.5 times, frozen fish $-39 \%$, apples $29 \%$, potatoes $-28 \%$, beef $-24 \%$ (Drobnitsa, 2015). Statistics show that, despite the fact that food imports in 2017 continues to dominate over exports, it is obvious a significant decrease of this ratio for the period from 2013 to 2017 (Table 2):

Table 2. Indicators of foreign trade in food of the Russian Federation in 2013-2017 (Ministry of Agriculture, 2018)

\begin{tabular}{|c|c|c|l|}
\hline Year & $\begin{array}{c}\text { exports of food } \\
\text { and agricultural } \\
\text { raw materials, } \\
\text { billion dollars }\end{array}$ & $\begin{array}{l}\text { Food and } \\
\text { agricultural } \\
\text { imports, } \\
\text { billion dollars. }\end{array}$ & $\begin{array}{l}\text { Balance of import }- \\
\text { export of food and } \\
\text { agricultural raw } \\
\text { materials, } \\
\text { billion dollars }\end{array}$ \\
\hline 2013 & 16,2 & 43,2 & 27 \\
\hline 2014 & 19 & 39,9 & 20,9 \\
\hline 2015 & 16,2 & 26,6 & 8 \\
\hline 2016 & 17,1 & 25,1 & 8,2 \\
\hline 2017 & 20,7 & 28,9 & \\
\hline
\end{tabular}

The main commodity items in the structure of agricultural imports in 2017 in value terms were edible fruits and nuts $(16.2 \%$, including citrus fruits $-4.1 \%$, bananas $4 \%$ ), meat and meat products $(9.3 \%$, including cattle meat $-4.3 \%$, pork $-2.8 \%$, poultry meat and ice cream $-1.2 \%)$, dairy products $(8.3 \%$, including cheese and cottage cheese $-3.2 \%$ ), alcoholic and non-alcoholic products $(8.6 \%) . \%$ ), vegetables and some edible roots, tubers (6.2\%), fish, crustaceans and molluscs (5.6\%). In 2017, compared to 2016, imports of chilled and frozen cattle meat decreased by $2.2 \%$ (to 358.7 thousand tons), butter- by $6.3 \%$ (to 89.7 thousand tons), soybeans - by $2 \%$ (to 2236.7 thousand tons), coconut oil (copra), palm kernel oil or babassu oil - by $19.3 \%$. 
Taking into account that the integration process within the Eurasian economic Union, one of the leaders of which is Russia, is currently actively underway, taking into account the social importance of agro-industrial complex and the need to saturate the internal market of the Union with its own quality and affordable products, it is necessary to consider the issue of joint import substitution products within the EAEU. According to the agreements concluded within the framework of the EAEU, a single agro-industrial policy is implemented in the territory of the integration Association, "the main purpose of which is the effective implementation of the resource potential of the member States to optimize the production of competitive agricultural products and food, meet the needs of the common agricultural market, as well as increasing the export of agricultural products and food. Implementation of the coordinated (coordinated) agro-industrial policy provides the solution of the following tasks:

1) balanced development of agricultural and food production and markets;

2) ensuring fair competition between the subjects of the member States, including equal conditions of access to the common agricultural market;

3 ) unification of requirements related to the circulation of agricultural products and food;

4) protection of the interests of producers of member States in the domestic and foreign markets (EEC, 2014).

A serious step towards the implementation of the common agro-industrial policy was the decision to put into operation the subsystem of the agro-industrial complex of the EAEU member States within the framework of the Union integrated information system.

The agro- industrial subsystem provides seven General information resources, including the unified register of varieties of agricultural plants, the resource of these forecast indicators of The agro- industrial complex and data on prices for agricultural products and food products. In addition, the information system includes data resources on national programs for the development of production of sensitive agricultural products, breeding animals and breeding achievements, information on state support for agriculture, research work in agriculture. The subsystem will allow to link together the industrial, scientific organizations and consumers, to establish a unified registers and databases, to digitize the process of integration and interaction (EEC, 2018).

According to the Eurasian economic Commission, $61 \%$ of the total turnover of the EAEU countries is imports. As a rule, these are the goods that can be produced on the territory of the Union. In monetary terms, about $\$ 26.5$ billion is spent on the purchase of products, for example, in such a position as berries (raspberry, currant, cranberry, etc), the EAEU in 2016 imported products for $\$ 426$ million, which is 20 times more than the costs of Kyrgyzstan for the entire agricultural sector for the year. Meat of various kinds was imported to the Union for \$ 1.9 billion, which is almost twice as much as all budget expenditures of Kazakhstan for agriculture in 2015. 
Liqueurs and other alcoholic tinctures were imported for $\$ 664$ million, which is three times more than the five-year budget of Armenia for agriculture (EEC, 2017). The development of import substitution in agro- industrial sector can stimulate initiatives that will lead to increased competitiveness of agricultural production of the EAEU member States. For this purpose, it was necessary to update and improve the quality of agricultural production and material and technical resources, modernization and progressive transition to the elements of innovative development of the industry, diversification of production, including through the introduction of technologies for deep and complex processing of food raw materials.

\section{Formation of a Unified Risk Management System}

Despite the declaration of common goals in the field of agro-industrial policy, our strategic partners such as Kazakhstan and Belarus have demonstrated their vulnerability when they were asked to ban the transit of goods under sanctions through the territory of the EAEU. After the introduction of Russia's retaliatory sanctions against products from the European Union, there were fears that banned goods will continue to be supplied to our market under the guise of manufactured in Belarus or Kazakhstan. These forecasts were confirmed and goods from the West, banned for import to the border, began to enter the Russian market under the guise of transit from the EAEU countries, not observing the rules and regulations for determining the country of origin of goods. The majority of foreign companies wishing to enter the Russian market bypassing the embargo, as well as to preserve the existing volumes of exports of sanctioned goods, falsify the certificates of the country of origin of goods. This problem shows the lack of joint responsibility for mutual support of the EAEU countries in a difficult situation for Russia, although according to the signed agreements in order to counter threats to national economic security, the EEA countries were obliged to observe and maintain allied solidarity, to use mechanisms to comply with the embargo and prevent re-export of prohibited goods from their territory.

The reason for this situation is, among other things, the lack of a common risk management system, namely a single database of the EAEU risk profiles. At the same time, illegal schemes of circumvention of the legislation of the Russian Federation to a certain extent affect the economic security of the member state of the EAEU through the territory of which manufacturers are trying to introduce sanctioned goods or products. Modernization potential of the risk management system in the mechanism of customs regulation of foreign economic activity of the EEU is constrained by the existing deficiencies of the regulation, which are presented in Figure 2.

Currently, there are the main types of risks that must be minimized in any state of the EAEU. These include understatement of the customs value of goods, declaration of false information about the country of origin of goods and unlawful requirement to provide tariff preferences. This also includes the statement of false information 
about the weight, quantity and name of goods, non-compliance with the established prohibitions and restrictions, inaccurate classification of goods under the single HS of the EAEU and non-compliance with intellectual property rights.

Figure 2. Factors affecting the effectiveness of risk management in the customs territory of the EAEU

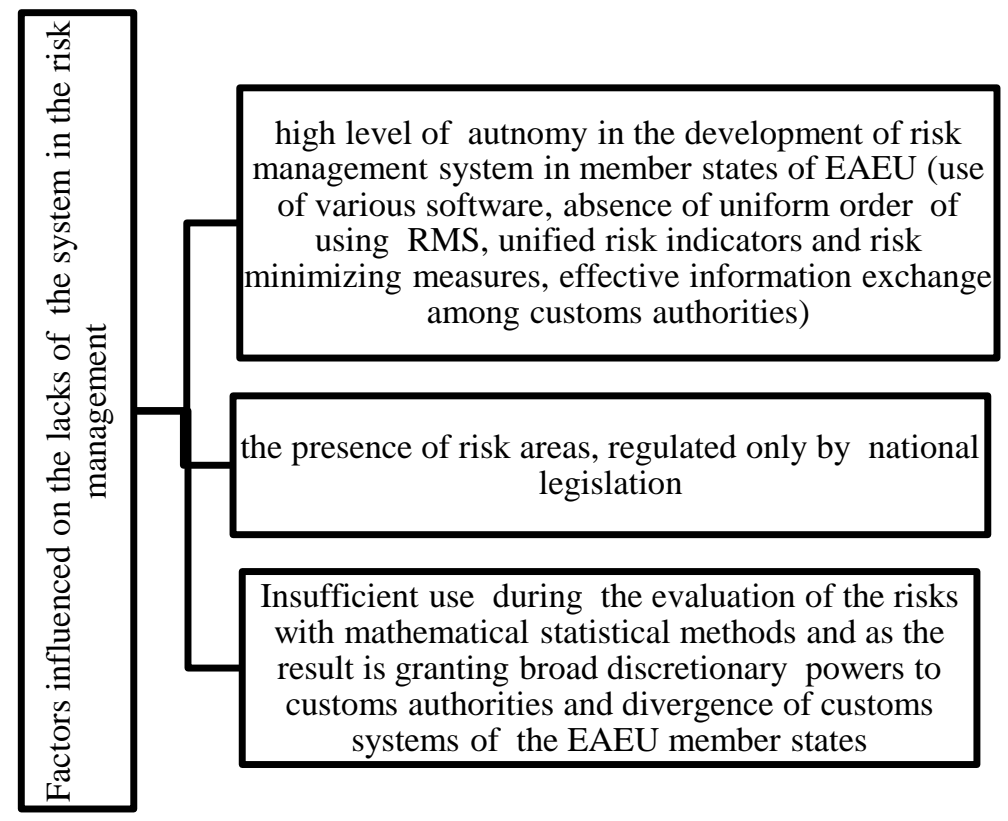

The disintegration of the EAEU member states in risk management does not contribute to a common policy of import substitution and undermines the economic security of our country. This phenomenon is due, first of all, to the lack of fixed legal norms in the customs code of the EAEU on a single risk management strategy, as well as the lack of interest of the EAEU member states in the implementation of a single policy of import substitution.

Improving the efficiency of risk management in the EAEU member States will help to protect national producers from imports and thus increase the growth of exports of EAEU products. At present, joint work on information exchange is already underway, joint special operations are being carried out to prevent the import of prohibited goods into the customs territory of the EAEU. The results of such work are formalized in the form of risk profiles in each state in its own way or not formalized, since law enforcement profiles are characterized by the maximum degree of information protection. We propose the creation of a common basis for the functioning of the customs risk management system of the Eurasian economic Union. This unified system of customs risk management of the EAEU should include the following interrelated elements (Figure 3): 
Figure 3. Elements of the EAEU common customs risk management system

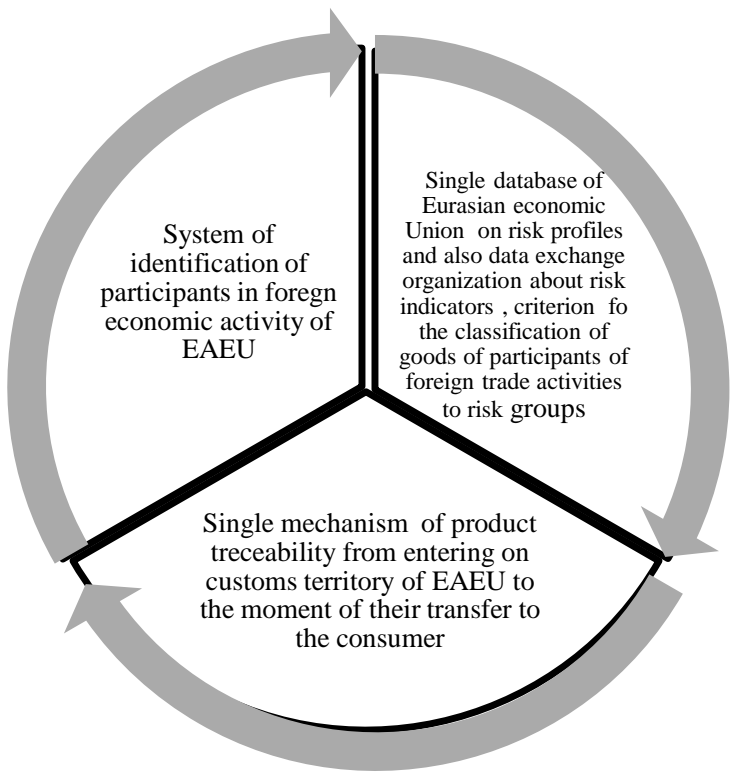

The implementation of these proposals is possible, firstly, when all the authorized bodies of the EAEU agree on the "road map", which provides for certain stages and tools for the introduction of a single base of the EAEU risk management system, and secondly, the coordination of specific areas, risk profiles. We schematically reflected the tools for creating a unified risk management system throughout the EAEU in Figure 4.

Figure 4. Tools for creating a unified risk management system on the territory of the EAEU

1. Development of infomation technologies in the customs authorities of the Russian Federation

2. Joint activities with the business community of member states of EAEU in order to increase entrepreneurs' interest for carrying out joint policy of import substitution

3. Development of single regulatory legal base which regulates the activity in customs bodies of member states of EAEU

We will comment on the main steps to form a unified risk management system.

1. The development of information technologies in the customs authorities is an integral part of the transition to a new stage of development of the customs service 
not only in Russia but also in all other EAEU member States. This is due to the need to use a single electronic signature for traders, ensuring automatic registration in the automated system of customs authorities of submitted documents and information, avoiding duplication of electronic information documents on paper, the creation of a single information platform of state bodies that control the cross-border movement of goods, with the possibility of using electronic data received from foreign States.

2. Carrying out joint activities with the business community of the EAEU member States in order to increase the interest of entrepreneurs in the joint policy of import substitution is associated with the need to interest the business in the profitability of joint import substitution, joint development of industrial production, agriculture, taking into account the potential of each of the EAEU member States, and, as a consequence, in the subsequent definition of common risk profiles.

3. The development of a single regulatory framework governing the activities of the customs authorities of the EAEU member States is an important mechanism that will contribute to the main goal of the EAEU to ensure conditions for the stable development of the economies of the member States in order to improve the living standards of the population, the formation of a single market of goods, services, capital and labor resources.

\section{Conclusion}

The creation of a unified risk management system of the EAEU will solve the following tasks:

- protection of the national economy of each member state of the EAEU from unlawful, illegal schemes of import of prohibited goods into the territory of the EAEU;

- full cooperation of customs authorities of the EAEU member States using a unified data base of the EAEU on the risk profiles with respect to the importation into the territory of the EAEU of items belonging to a certain risk, for example, in the direction of "country of origin" or "classification of goods»;

- reduction of the level of administrative offences and criminal cases against carriers of the EAEU member States;

- full control by the customs authorities of the Russian Federation over the movement of goods, which is classified according to the unified risk management system of the EAEU to a certain level of risk, on the customs territory of the EAEU from import to the end point. 


\section{References:}

Central Bank of the Russian Federation. 2018. Currency exchange rate database. Retrieved from URL: http://www.cbr.ru/currency_base/daily/.

Drobnitsa, I.K. 2015. Russian food embargo: support for domestic producers or hardships for consumers? BIKI, 4.

EEC. 2017. Cooperation of the EAEU countries in the sphere of agriculture can become an effective mechanism of import substitution-EEC Electronic resource/e Retrieved from https://export.by/news/eaec_members_cooperation_can_become_effective_for_impor t_substitution.

EEC. 2018. The EEC Board discussed issues of industrial cooperation in the EEC countries. Retrieved from http://www.eurasiancommission.org/ru/nae/news/Pages/26-12-20171.aspx.

EEC. 2014. Treaty on the Eurasian economic Union. Retrieved from http://www.consultant.ru/document/cons_doc_LAW_163855/.

Erokhina, E. 2017. Influence of import substitution policy on regional economic development. Problems of management theory and practice.

Gamidullaeva, L. 2018. Towards Combining the Innovation Ecosystem Concept with Intermediary Approach to Regional Innovation Development. International Journal of Economics \& Business Administration, 6(1), 39-53.

Government of the Russian Federation. 2008. The concept of long-term socio-economic development of the Russian Federation for the period up to 2020. Approved by government decree No. 1662-R of 17 November 2008. Retrieved from http://www.consultant.ru/document/cons_doc_LAW_82134/28c7f9e359e8af09d7244 d8033c66928fa27e527/.

Government of the Russian Federation. 2014. The decree of the President of Russia dated 06.08.2014 "On the application of certain special economic measures to ensure the security of the Russian Federation".

Government of the Russian Federation. 2017. The decree of the President of the Russian Federation from 13.05.2017 № 208 "On the Strategy of economic security of the Russian Federation for the period till 2030" // Retrieved from http://www.consultant.ru/document/cons_doc_LAW_216629/1d8dcf5824d5241136fa 09b9e9c672ac5d325365/.

Government of the Russian Federation. 2010. The doctrine of food security of the Russian Federation. Approved by presidential decree of January 30, 2010 №120. Retrieved from https://rg.ru/2010/02/03/prod-dok.html

Sibiryatkina, I.V., Fofonova, V.O. 2016. The Content of the Mechanism for the Company's Own and Borrowed Capital Optimization. Actual Directions of Scientific Research of the XXI Century: Theory and Practice, 6(26), 200-203.

Jabiev, A.P. 2015. Customs service of Russia in the conditions of international sanctions: challenges and opportunities to minimize them. International trade and trade policy, 3.

Kushnarenko, T.V., Kaplina, A.V., Tabakov, A.N., Fomina, I.B. 2018. Clustering as an Integration Pattern of Business Activity. European Research Studies Journal, Vol. XXI, Special Issue 1, 553-563.

Ministry of Agriculture. 2018. National report on the results of the program for the Development of Agriculture and Regulation of Agricultural Products, Raw Materials and Food Markets for 2013-2020/ Retrieved from http://mcx.ru/activity/statesupport/programs/program-2013-2020/. 
Ministry of Agriculture. 2017. State Program for the Development of Agriculture and Regulation of Agricultural Products, Raw Materials and Food Markets for 2013-2020/ Retrieved from http://mcx.ru/activity/state-support/programs/program-2013-2020/.

Terenina, I.V., Kostoglodov, D.D., Osadchaya, N.A., Mikhailichenko, E.V. 2018. Principles and Methods of Efficient Organization of Vertically Integrated Structures in the AgroIndustrial Sector. European Research Studies Journal, Vol. XXI, Special Issue 1, 496505 .

Varkey, J. 2018. The Russian economy and sanctions. Assessment of the consequences of the Ukrainian conflict//note by the Observatory Analytical center. Retrieved from URL: http://obsfr.ru/fi leadmin/Policy_paper / PP9_RU.pdf.

Yandex: economic news. 2018. Dynamics of oil prices Brent Retrieved from URL: https://news.yandex.ru/quotes/1006.html. 